\title{
EXPRESSION OF IGFBP6, IGFBP7, NOV, CYR61, WISP1 AND WISP2 GENES IN U87 GLIOMA CELLS IN GLUTAMINE DEPRIVATION CONDITION
}

\author{
O. H. MINCHENKO ${ }^{1}$, A. P. KHARKOVA ${ }^{1}$, D. O. MINCHENKO ${ }^{1,2}$, L. L. KARBOVSKYI \\ ${ }^{1}$ Palladin Institute of Biochemistry, National Academy of Sciences of Ukraine, Kyiv; \\ e-mail: ominchenko@yahoo.com; \\ ${ }^{2}$ Bohomolets National Medical University, Kyiv, Ukraine
}

We have studied gene expression of insulin-like growth factor binding proteins in U87 glioma cells upon glutamine deprivation depending on the inhibition of IRE1 (inositol requiring enzyme-1), a central mediator of endoplasmic reticulum stress. We have shown that exposure of control glioma cells upon glutamine deprivation leads to down-regulation of NOV/IGFBP9, WISP1 and WISP2 gene expressions and up-regulation of CYR61/IGFBP10 gene expression at the mRNA level. At the same time, the expression of IGFBP6 and IGFBP7 genes in control glioma cells was resistant to glutamine deprivation. It was also shown that the inhibition of IRE1 modifies the effect of glutamine deprivation on the expression of all studied genes. Thus, the inhibition of IRE1 signaling enzyme enhances the effect of glutamine deprivation on the expression of CYR61 and WISP1 genes and suppresses effect of the deprivation on WISP2 gene expression in glioma cells. Moreover, the inhibition of IRE1 introduces sensitivity of the expression of IGFBP6 and IGFBP7 genes to glutamine deprivation and removes this sensitivity to NOV gene. We have also demonstrated that the expression of all studied genes in glioma cells growing with glutamine is regulated by IRE1 signaling enzyme, because the inhibition of IRE1 significantly down-regulates IGFBP6 and NOV genes and up-regulates IGFBP7, CYR61, WISP1, and WISP2 genes as compared to control glioma cells. The present study demonstrates that glutamine deprivation condition affects most studied IGFBP and WISP gene expressions in relation to IRE1 signaling enzyme function and possibly contributes to slower glioma cell proliferation upon inhibition of IRE1.

K e y word s: mRNA expression, IGFBP6, IGFBP7, NOV/IGFBP9, CYR61/IGFBP10, WISP1, WISP2, IRE1 inhibition, glutamine deprivation, glioma cells.

I nsulin-like growth factor binding proteins (IGFBPs) play an important role in the regulation of numerous metabolic and proliferative processes mainly through interaction with IGF1 and IGF2, their cell surface receptors, as well as insulin receptor, alter the half-life of the IGFs and modify their biological activity because they contain insulinlike growth factor (IGF) binding domain. It is well known that insulin-like growth factors and the signal transduction networks they regulate play important roles in metabolic diseases as well as in tumorigenesis and metastasis [1,2]. IGFBPs participate in endoplasmic reticulum stress, which is an important factor of tumor growth, insulin resistance, and obesity [3-5]. Therefore, there is the cross talk between IGF and insulin receptor signaling pathways at the receptor level or at downstream signaling level. A formation of hybrid receptor isoforms between receptors for IGF1 and insulin, which are sensitive to the stimulation of all three IGF axis ligands, as well as hybrid receptors of IGF1/insulin receptor with other tyrosine kinase potentiate the transformation of cells, tumorigenesis, and tumor neovascularization [6].

The IGFBPs bind and regulate the availability of both insulin-like growth factors and inhibit or stimulate the growth promoting effects of these growth factors through IGF/INS receptors and through other signaling pathways. They regulate cell proliferation and survival as well as angiogenesis and cancer cell migration. Moreover, both negative and positive correlations between levels of IGF-1/IGF$1-\mathrm{R}$ and clinical outcomes in head and neck cancer have been reported [6]. IGFBPs are now understood to have many actions beyond their endocrine role in IGF transport [6]. These binding proteins function both in the cells and extracellular matrix to regulate cell proliferation and survival and involved in tumor 
development and progression as well as resistance to treatment. In addition to their canonical ligands (IGF1 and IGF2), they play an important role in the regulation of various processes including transcription, because they interact with many proteins $[6,7]$. Therefore, IGFBP6 preferentially binds to IGF2 and also has IGF-independent effects, including inhibition of angiogenesis and promotion of cancer cell migration [8]. Moreover, IGFBP6 regulate cell proliferation and apoptosis: down-regulation of this gene expression leads to inhibition of cell proliferation and to increased apoptotic cell death. It is interesting to note that apoptosis can also be regulated through IGF1 receptor; however, there is data that IGFBP6 can also suppress cell proliferation [9].

The IGFBP7, which is also known as insulinlike growth factor binding protein-related protein 1 (IGFBPRP1), has a conserved structural homology with other members of IGFBP family. It is interesting to note that it has a low affinity for IGFs and high affinity for insulin, suggesting that IGFBP7 may have a biological function distinct from other members of the IGFBP family. Moreover, IGFBP7 has diverse biological functions, regulating cell proliferation, apoptosis and senescence; it may also play a key role in vascular biology [6]. It elicits its biological effects by both insulin/IGF-dependent and -independent mechanisms. It was also shown that IGFBP7 can bind to unoccupied IGF1 receptor, blocks its activation by insulin-like growth factors and suppresses downstream signaling, thereby inhibiting protein synthesis, cell growth, and survival [10]. Increasing evidence suggests that IGFBP7 acts as a tumor suppressor [6].

The NOV/IGFBP9 (nephroblastoma overexpressed) and CYR61/IGFBP10 (cysteine-rich angiogenic inducer 61), which play a role in cell growth regulation and are involved in angiogenesis, inflammation and matrix remodeling are members of IGFBP and CNN families of regulatory proteins [11]. The WNT1 inducible signaling pathway (WISP) proteins WISP1/CCN4 and WISP2/CCN5 are downstream in the WNT1 signaling pathway and are also relevant to malignant transformation, cancer cell surviving, invasion and motility [12-14]. Furthermore, elevated levels of WISP1/CCN4 and CYR61/ $\mathrm{CCN} 1$ in primary breast cancers are associated with more advanced features [14].

Multiple studies have clarified the link between cancer and endoplasmic reticulum stress, which controls different processes, including cell proliferation and surviving as well as circadian rhythms [15-18]. The IRE1 (inositol requiring enzyme-1) is a central mediator of the unfolded protein response and an important component of tumor growth. Moreover, its blockade leads to a suppression of tumor growth through down-regulation of the proliferation processes and angiogenesis $[19,20]$. It contributes to the expression profile of many regulatory genes resulting in proliferation, angiogenesis, and apoptosis $[15,20$, 21]. The IRE1 has two enzymatic activities: kinase, which is responsible for autophosphorylation and some gene expressions, and endoribonuclease, which is responsible for degradation of a specific subset of mRNA and alternative splicing of the XBP1 (X-box binding protein 1) transcription factor mRNA for control of the expression of numerous unfolded protein response-specific genes [22, 23].

The endoplasmic reticulum stress responsesignalling pathway is tightly linked to the neovascularization, tumor growth and cell death processes as well as to suppression of insulin receptor signaling through activation of c-Jun N-terminal kinase (JNK) and subsequent serine phosphorylation of IRS1. The endoplasmic reticulum has an essential position as a signal integrator in the cell and is instrumental in the different phases of tumor progression because the signaling pathways elicited by endoplasmic reticulum stress sensors have connections with metabolic pathways and with other plasma membrane receptor signaling networks [24].

Ablation of IRE1 function has been shown to result in a significant anti-proliferative effect in glioma growth through down-regulation of prevalent pro-angiogenic factors and up-regulation of antiangiogenic genes as well as by modification of these genes expression by glutamine deprivation [20,25]. Malignant gliomas are highly aggressive tumors with very poor prognosis and to date there is no efficient treatment available. The moderate efficacy of conventional clinical approaches therefore underlines the need for new therapeutic strategies. Glutamine and glucose are important substrates for glutaminolysis and glycolysis, which are important to glioma development and a more agressive behaviour [26-28]. It was recently shown that glioblastoma proliferation under glutamine deprivation depends on glutamate-derived glutamine synthesis through glutamine synthetase activity, which fuels nucleotide biosynthesis and supports growth of glutaminerestricted glioblastoma $[29,30]$. A better knowledge of tumor responses to glucose or glutamine depri- 
vation conditions is required to elaborate therapeutical strategies of cell sensibilization, based on the blockade of survival mechanisms [10, 31]. However, the executive mechanisms of the exhibited antiproliferative effects of IRE1 inhibition are not yet known. It is possible that this anti-proliferative effect is also realized through mediation by IFGBPs and its receptors signaling, which are integrated into the unfolded protein response signaling pathways, to regulate cell proliferation and surviving $[6,8,11,32$, 33]. Previously it was shown that insulin-like growth factor binding proteins and $\mathrm{CCN}$ family proteins such as IGFBP6, IGFBP7, NOV/IGFBP9, CYR61/ IGFBP10, WISP1, and WISP2 are possibly involved in the regulation of glioma cells proliferation by IRE1, because inhibition of signaling enzyme IRE1 significantly affects the expression of all these genes and modifies their hypoxic regulation [34].

The main goal of this study was to investigate the role of expression of genes encoding the insulin-like growth binding proteins with different affinity for IGF proteins (IGFBP6, IGFBP7, NOV/ IGFBP9, CYR61/IGFBP10, WISP1, and WISP2) in U87 glioma cell line and its subline with IRE1 loss of function in glutamine deprivation condition for evaluation of its possible significance in the control of tumor growth through IRE1 mediated endoplasmic reticulum stress signaling.

\section{Materials and Methods}

Cell Lines and Culture Conditions. The glioma cell line U87 (HTB-14) was obtained from ATCC (USA) and grown in high glutamine (4.5 g/l) Dulbecco's modified Eagle's minimum essential medium (DMEM; Gibco, Invitrogen, USA) supplemented with glutamine $(2 \mathrm{mM}), 10 \%$ fetal bovine serum (Equitech-Bio, Inc., USA), penicillin (100 units/ml; Gibco, USA) and streptomycin $(0.1 \mathrm{mg} / \mathrm{ml}$; Gibco) at $37{ }^{\circ} \mathrm{C}$ in a $5 \% \mathrm{CO}_{2}$ incubator.

The sublines of U87 glioma cells used in this study were described previously [20, 21]. One subline was obtained by selection of stable transfected clones with overexpression of vector pcDNA3.1, which was used for creation of dnIRE1. This untreated subline of glioma cells (control glioma cells) was used as control 1 in the study of the effect of glutamine deprivation on the expression level of different IGFBP and related genes. The other subline was obtained by selection of a stable transfected clone with overexpression of IRE1 dominant/negative construct (dn-IRE1) and has suppressed both protein kinase and endoribonuclease activities of this signaling enzyme (clone 1C5) [20]. The expression level of the studied genes in these cells was compared with cells, transfected by vector (control 1), but this subline was also used as control 2 for investigation the effect of glutamine deprivation on gene expressions under blockade of both enzymatic activities of IRE1. The efficiency of IRE1 suppression in this glioma cell subline was estimated previously [21] by determining the expression level of the XBP1 alternative splice variant, a key transcription factor in the IRE1 signaling, and the level of the phosphorylated isoform IRE1 using cells treated by tunicamycin $(0.01 \mathrm{mg} / \mathrm{ml}$ during $2 \mathrm{~h})$. The both sublines of glioma cells are grown with the addition of geneticin (G418), while these cells were carrying empty vector pcDNA3.1 or dn-IRE1 construct.

Glutamine deprivation condition was created by changing the complete DMEM medium into culture plates on the medium without glutamine (Gibco) and plates were exposed to this condition for $16 \mathrm{~h}$.

RNA isolation. Total RNA was extracted from glioma cells using Trizol reagent according to manufacturer's protocols (Invitrogen, USA) as described previously [35]. The RNA pellets were washed with $75 \%$ ethanol and dissolved in nuclease-free water. For additional purification RNA samples were re-precipitated with $95 \%$ ethanol and re-dissolved again in nuclease-free water. RNA concentration and spectral characteristics were measured using NanoDrop Spectrophotometer ND1000 (PEQLAB, Biotechnologie $\mathrm{GmbH}$ ). Absorption coefficients at 260/280 $\mathrm{nm}$ were in the range from 2.12 to 2.19 .

Reverse transcription and quantitative PCR analysis. QuaniTect Reverse Transcription Kit (QIAGEN, Germany) was used for cDNA synthesis according to manufacturer's protocol. The expression level of insulin-like growth factor binding proteins (IGFBP6, IGFBP7, IGFBP9/NOV, and IGFBP10/ CYR61) and WNT1 inducible signaling pathway proteins (WISP1 and WISP2) mRNAs as well as ACTB mRNA were measured in U87 glioma cells by real-time quantitative polymerase chain reaction using "Applied Biosystems 7500" (Applied Biosystems, USA) and Absolute qPCR SYBRGreen Mix (Thermo Fisher Scientific, ABgene House, UK). Polymerase chain reaction was performed in triplicate using specific primers (Sigma-Aldrich, USA).

For amplification of IGFBP 6 cDNA we used forward (5'-GCTGTTGCAGAGGAGAATCC $-3^{\prime}$ and reverse (5'-GGTAGAAGCCTCGATGGT- 
CA-3') primers. The nucleotide sequences of these primers correspond to sequences $397-416$ and 655636 of human IGFBP6 cDNA (GenBank accession number NM_002178). The size of amplified fragment is $259 \mathrm{bp}$.

The amplification of IGFBP7 cDNA for real time RCR analysis was performed using two oligonucleotides primers: forward - 5'-AGCTGTGAGGTCATCGGAAT- $3^{\prime}$ and reverse - 5'TATAGCTCGGCACCTTCACC- $3{ }^{\prime}$. The nucleotide sequences of these primers correspond to sequences 572-591 and 882-863 of human IGFBP7 cDNA (GenBank accession number NM_001553). The size of amplified fragment is $311 \mathrm{bp}$.

The amplification of NOV/IGFBP9/CCN3 cDNA for real time RCR analysis was performed using two oligonucleotides primers: forward $-5^{\prime}-$ GCGAAGAAAGTCTCGTTTGG- ${ }^{\prime}$ ' and reverse 5'-ACACCAGACAGCATGAGCAG-3'. The nucleotide sequences of these primers correspond to sequences 176-195 and 420-401 of human IGFBP9 cDNA (GenBank accession number NM_002514). The size of amplified fragment is $245 \mathrm{bp}$.

For amplification of CYR61/IGFBP10/CCN1 cDNA we used forward (5'-CTCCCTGTTTTTGGAATGGA- $3^{\prime}$ and reverse (5'-TGGTCTTGCTGCATTTCTTG- $3^{\prime}$ ) primers. The nucleotide sequences of these primers correspond to sequences 852-871 and 1092-1073 of human IGFBP10 cDNA (GenBank accession number NM_001554). The size of amplified fragment is $241 \mathrm{bp}$.

The amplification of WNT1 inducible signaling pathway protein 1 (WISP1), also known as CCN4, cDNA for real time RCR analysis was performed using two oligonucleotides primers: forward $-5^{\prime}-$ GACTTTACCCCAGCTCCACT- 3 ' and reverse - 5'GTAGTCACAGTAGAGGCCCC -3 '. The nucleotide sequences of these primers correspond to sequences 203-222 and 415-396 of human WISP1 cDNA (GenBank accession number NM_003882). The size of amplified fragment is $213 \mathrm{bp}$.

For amplification of WISP2/CCN5 cDNA we used forward (5'-CTGTATCGGGAAGGGGAGAC- $3^{\prime}$ and reverse (5'-GGGAAGAGACAAGGCCAGAA-3') primers. The nucleotide sequences of these primers correspond to sequences $463-482$ and 709-690 of human WISP2 cDNA (GenBank accession number NM_003881). The size of amplified fragment is $247 \mathrm{bp}$.

The amplification of $\beta$-actin (ACTB) cDNA was performed using forward - 5'-GGACTTCGAG-
CAAGAGATGG $-3^{\prime}$ and reverse - 5'- AGCACTGTGTTGGCGTACAG $-3^{\prime}$ primers. These primer nucleotide sequences correspond to 747-766 and 980-961 of human ACTB cDNA (GenBank accession number NM_001101). The size of amplified fragment is $234 \mathrm{bp}$. The expression of $\beta$-actin mRNA was used as control of analyzed RNA quantity. The primers were received from Sigma-Aldrich (St. Louis, MO, USA).

Quantitative PCR analysis was performed using a special computer program "Differential expression calculator". The values of IGFBP6, IGFBP7, NOV/GFBP9, CYR61/IGFBP10, WISP1, WISP2, and $A C T B$ gene expressions were normalized to the expression of $\beta$-actin mRNA and represented as percent of control $(100 \%)$. All values are expressed as mean \pm SEM from triplicate measurements performed in 4 independent experiments. The amplified DNA fragments were also analyzed on a $\%$ agarose gel and that visualized by SYBR* Safe DNA Gel Stain (Life Technologies, Carlsbad, CA, USA).

Statistical analysis. Statistical analysis was performed using Excel program as described previously [36]. All values are expressed as mean \pm SEM from triplicate measurements performed in 4 independent experiments.

\section{Results and Discussion}

To determine if glutamine deprivation affects the expression of a subset of genes encoding for different insulin-like growth factor binding proteins through the IRE1 branch of endoplasmic reticulum stress response, we investigated the effect of glutamine deprivation condition on mRNA expression levels of different members of IGFBP and CCN families, which can participate in the regulation of glioma growth through insulin-like growth factor receptors as well as through other signaling pathways and mechanisms.

To investigate a possible role of endoplasmic reticulum stress signaling mediated by signaling enzyme IRE1 in the expression of insulin-like growth factor binding protein gene IGFBP6 and its sensitivity to glutamine deprivation we studied the effect of glutamine deprivation condition on this gene expression in glioma cells with functional IRE1 (control glioma cells) and cells without enzymatic activities of this signaling enzyme. As shown in Fig. 1, the expression level of IGFBP6 mRNA does not change significantly upon glutamine deprivation in control glioma cells in comparison with the control 1 , but 
is up-regulated by $+20 \%$ in cells with suppressed function of signaling enzyme IRE1 as compared to control 2.

We next tested the sensitivity of IGFBP7 gene to glutamine deprivation condition and whether IRE1 also participates in the regulation of this gene expression upon glutamine deprivation. As shown in Fig. 2, the expression of IGFBP7 gene is also resistant to glutamine deprivation in control glioma cells, but in cells without IRE1 signaling enzyme the expression of this gene is down-regulated by glutamine deprivation condition in comparison with corresponding control (control 2).

Next we investigated the cysteine-rich regulatory proteins NOV/IGFBP9/CCN3 and CYR61/IGFBP10/CCN1, which have insulin-like growth factor binding domain and are members of $\mathrm{CCN}$ family proteins, associate with the extracellular matrix and play an important role in cancer development by

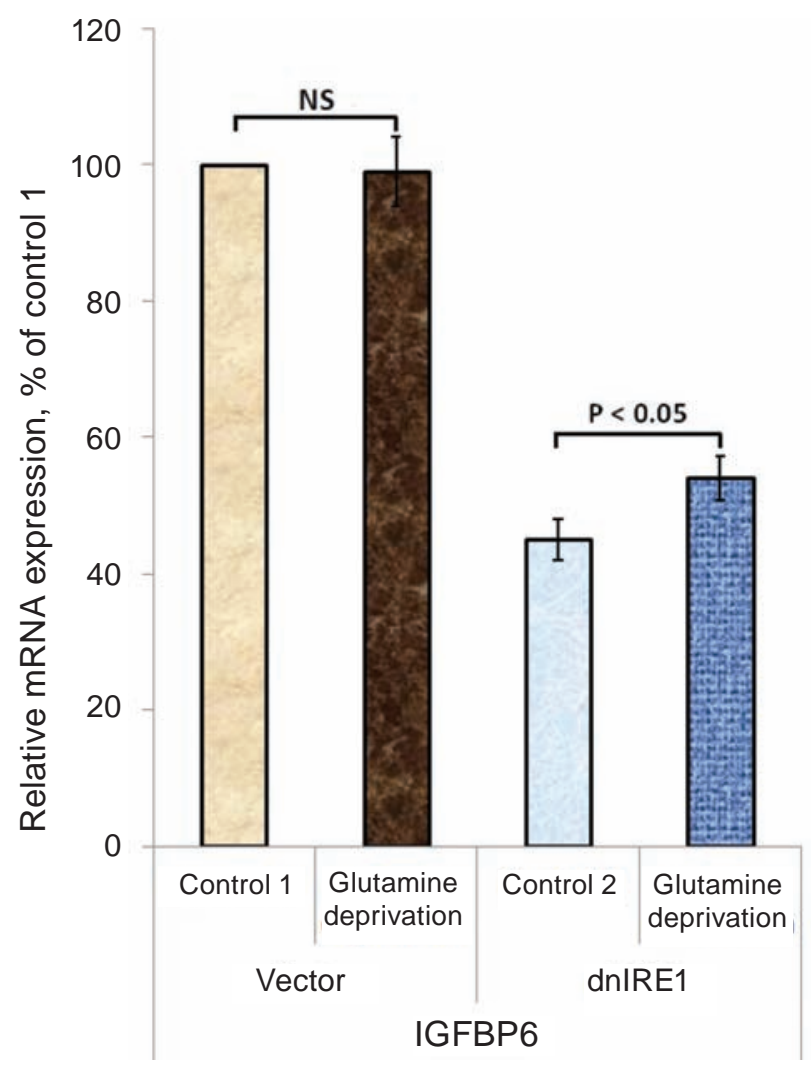

Fig. 1. Expression level of insulin-like growth factor binding protein 6 (IGFBP6) mRNA in control U87 glioma cells (Vector) and cells with inhibition of the IRE1 (dnIRE1) upon glutamine deprivation measured by qPCR. Values of IGFBP6 mRNA expressions were normalized to $\beta$-actin $m R N A$ level and represented as percent of control 1 (100\%); $n=4$ regulation of angiogenesis, cell migration and proliferation [36, 37]. We tested how glutamine deprivation condition affects these insulin-like growth factor binding protein genes and how IRE1 inhibition modifies the effect of glutamine deprivation on the expression of NOV and CYR61 genes. As shown in Fig. 3 and 4, the expressions of NOV and CYR61 genes are sensitive to glutamine deprivation, but the expression changes in diverse ways. Thus, the exposure of the control glioma cells upon glutamine deprivation decreases the expression of NOV gene $(-29 \%)$ and induces CYR61 gene expression $(+34 \%)$. However, inhibition of IRE1 eliminates the effect of glutamine deprivation on NOV gene expression in glioma cells, but enhances the expression of CYR61 gene ( $+68 \%$ ) (Fig. 3 and 4). Thus, inhibition of IRE1 signaling enzyme function modifies the expression level of NOV and CYR61 mRNAs in gene-specific manner.

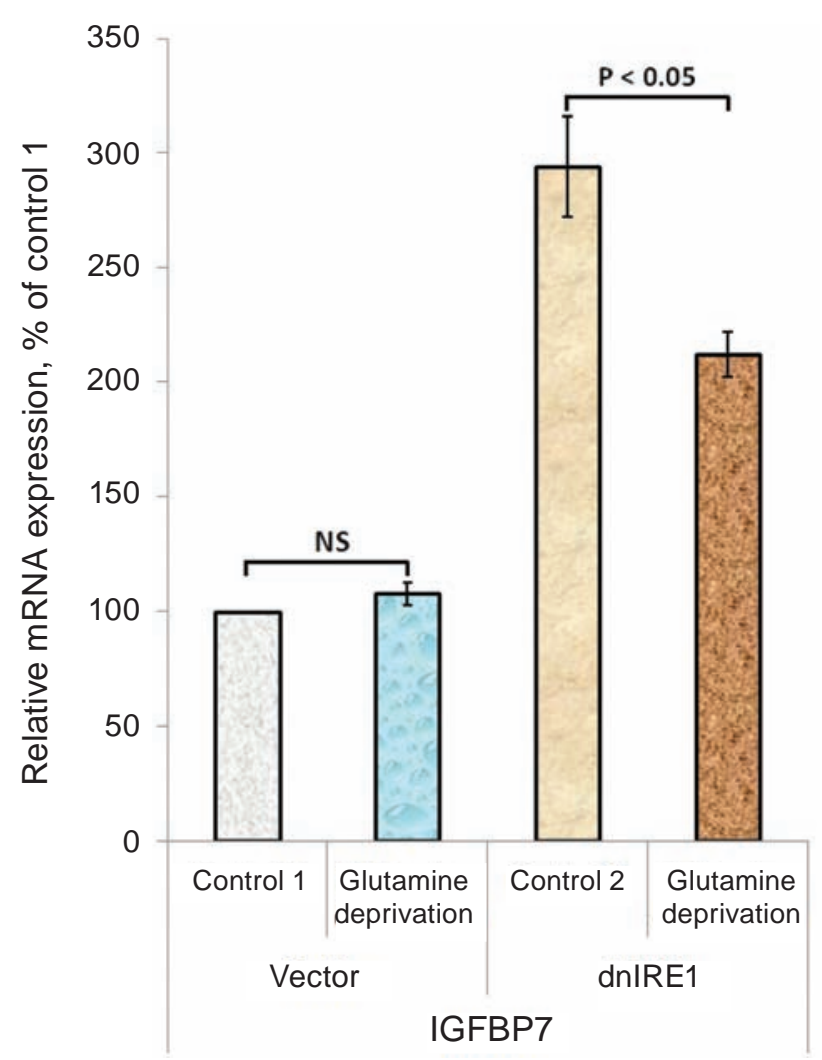

Fig. 2. Expression level of insulin-like growth factor binding protein 7 (IGFBP7) mRNA in control U87 glioma cells (Vector) and cells with inhibition of the IRE1 (dnIRE1) upon glutamine deprivation measured by qPCR. Values of IGFBP7 mRNA expressions were normalized to $\beta$-actin $m R N A$ level and represented as percent of control 1 (100\%); $n=4$ 


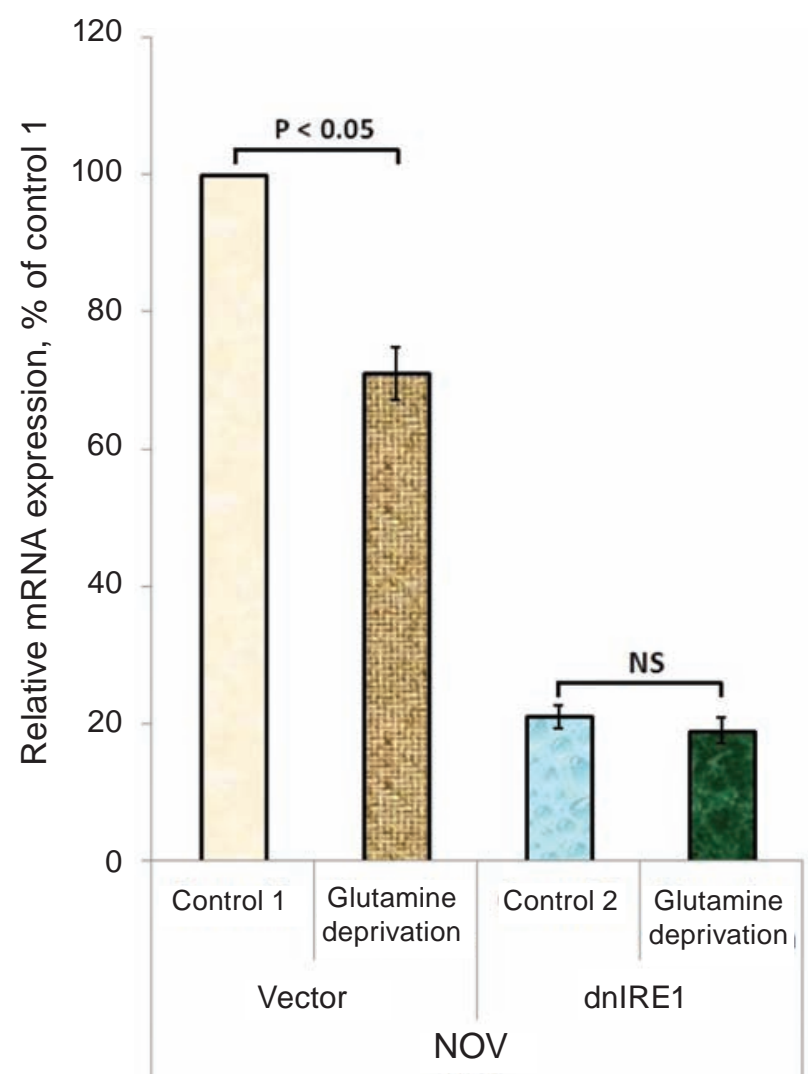

Fig. 3. Expression level of nephroblastoma overexpressed protein (NOV/IGFBP9) mRNA in control U87 glioma cells (Vector) and cells with inhibition of the IRE1 (dnIRE1) upon glutamine deprivation measured by qPCR. Values of NOV mRNA expressions were normalized to $\beta$-actin $m R N A$ level and represented as percent of control 1 (100\%); $n=4$

We next studied the effect of glutamine deprivation condition on the expression of WNT1 inducible signaling pathway proteins (WISP1 and WISP2), which have IGF binding domain and are members of CCN family proteins as well as NOV/IGFBP9/CCN3 and CYR61/IGFBP10/CCN1. As shown in Fig. 5, the expression of WISP1/CCN4 gene at mRNA level is down-regulated by glutamine deprivation both in cells with native IRE1 and cells with inhibited function of IRE1 signaling enzyme: $-18 \%$ in control glioma cells and $-68 \%$ (more than 3 -fold) in cells with a deficiency of IRE1 enzyme function.

Significant up-regulation was also shown for the expression of WISP2/CCN5 gene upon glutamine deprivation in both types of glioma cells: 2.6 -fold in control glioma cells and 1.8-fold in cells without IRE1 enzyme function as compared to corresponding controls (Fig. 6). Moreover, the inhibition of

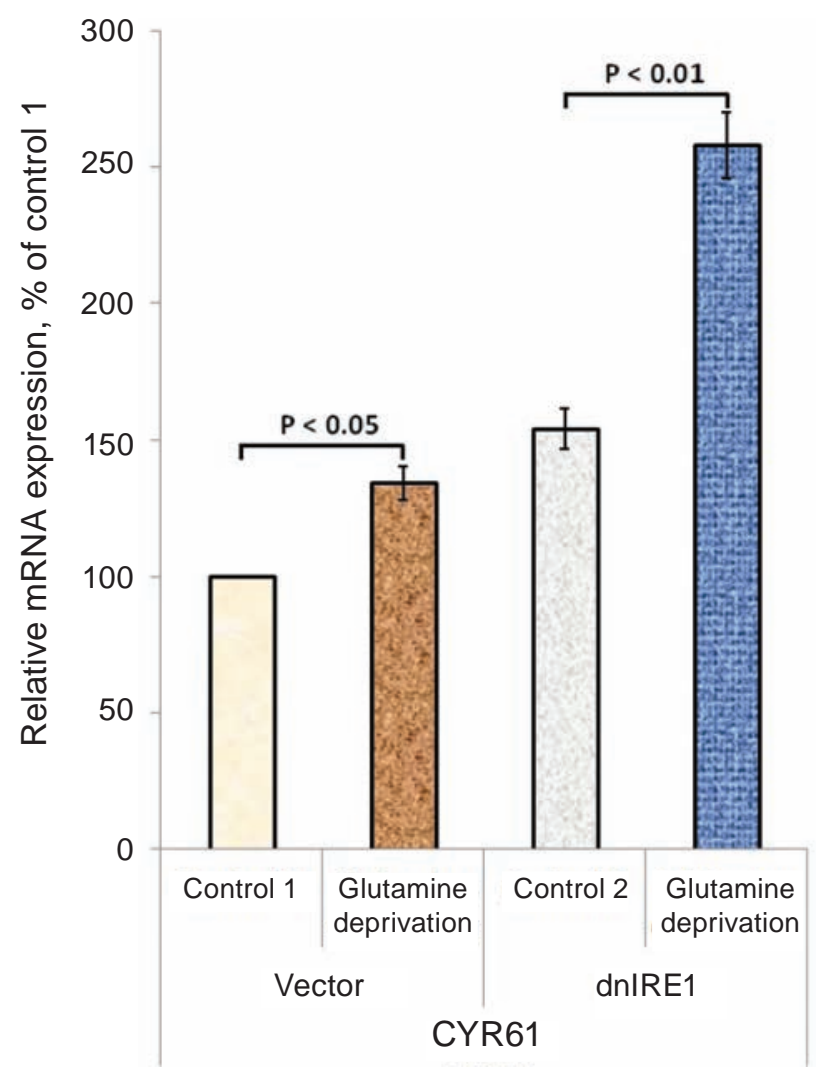

Fig. 4. Expression of cysteine-rich angiogenic inducer 61 (CYR61/IGFBP10), also known as CCN1 (CCN family member 1), mRNA in control U87 glioma cells (Vector) and cells with a blockade of the IRE1 by dnIRE1 (dnIRE1) measured by qPCR. Values of CYR61 mRNA expressions were normalized to $\beta$-actin $m R N A$ level and represented as percent of control 1 (100\%); $n=4$

IRE1 strongly up-regulated the expression of WISP2/ CCN5 gene at mRNA level in glioma cells in normoxic condition (3.6-fold) as compared to control 1.

Additionally, we analyzed the effect of hypoxic condition on the expression level of CYR61, WISP1, and WISP2 mRNA in glioma cells with intact and inhibited IRE1 enzyme function in conditions when the both controls (control 1 and control 2) are established as $100 \%$ to more precisely clarify the difference in the sensitivity of these gene expressions to glutamine deprivation in respect to inhibition of IRE1. As shown in Fig. 7, there are statistically significant differences in the expression levels of CYR61, WISP1, and WISP2 mRNA in control glioma cells and cells without IRE1 function exposure upon glutamine deprivation: 2.0-fold for CYR61, 3.8-fold for WISP1, and 2.2-fold for WISP2. 


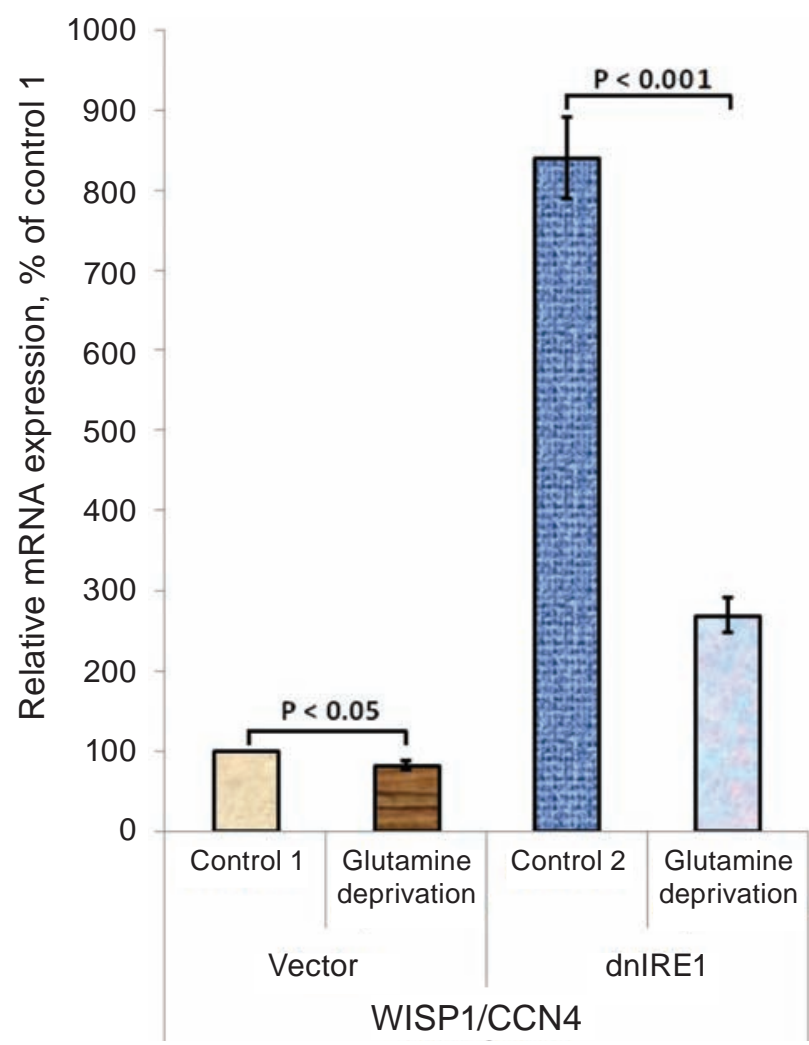

Fig. 5. Expression of WNT1 inducible signaling pathway protein 1 (WISP1), also known as CCN4, mRNA in control U87 glioma cells (Vector) and cells with a blockade of the IRE1 by dnIRE1 (dnIRE1) measured by qPCR. Values of WISP1 mRNA expressions were normalized to $\beta$-actin mRNA level and represented as percent of control 1 (100\%); $n=4$

In this work we studied the expression of genes encoded different insulin-like growth factor binding proteins in glioma cells with inhibition of IRE1 signaling enzyme function upon glutamine deprivation for evaluation of possible significance of these genes in the control of glioma growth through endoplasmic reticulum stress signaling mediated by IRE1 and glutamine deprivation. Investigation of the expression of different genes of IGFBP and CCN families in glioma cells upon glutamine deprivation in respect of inhibition of IRE1 signaling is very important for understanding of malignant tumor growth mechanisms, because glutamine deprivation, as well as nutrient deprivation play essential role in the control of tumor progression [32]. Thus, our results are consistent with numerous data $[27,29,30]$ that glutamine deprivation associated with malignant progression through the endoplasmic reticulum unfolded protein response, but mechanism how malignant cells cope

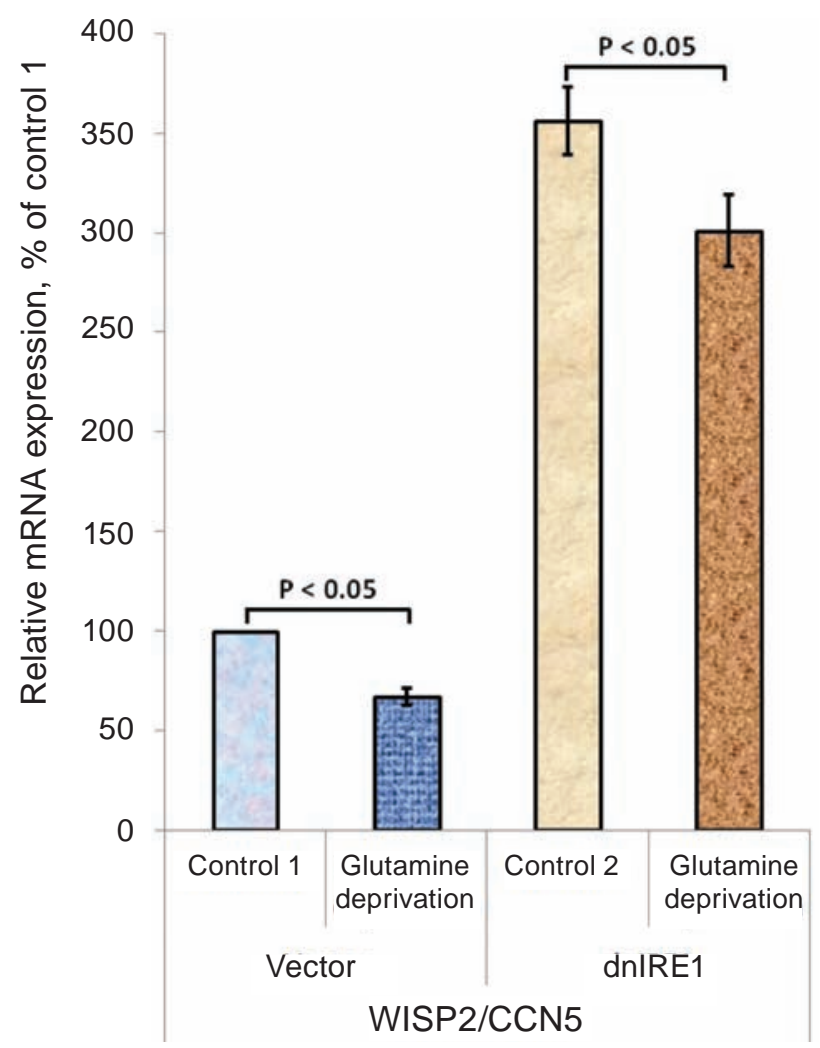

Fig. 6. Expression of WNT1 inducible signaling pathway protein 2 (WISP2), also known as CCN5, mRNA in control U87 glioma cells (Vector) and cells with a blockade of the IRE1 by dnIRE1 (dnIRE1) measured by qPCR. Values of WISP2 mRNA expressions were normalized to $\beta$-actin $m R N A$ level and represented as percent of control 1 (100\%); $n=4$

with potentially lethal metabolic stress induced by glutamine deprivation remains poorly understood.

The growing tumor requires the endoplasmic reticulum stress as well as glutamine deprivation and nutrient deprivation, which initiate the endoplasmic reticulum stress for own neovascularization and growth, for apoptosis inhibition [19, 20, 24, 25]. Cell proliferation is strongly dependent upon glutamine deprivation and glycolysis because there is the molecular connection between cell cycle progression and the provision of substrates essential for this purpose [28, 30]. Glutamate-derived glutamine is now shown to satisfy the glutamine needs of glioblastoma, because glutamine synthetase activity fuels nucleotide biosynthesis and supports growth of glutamine-restricted glioblastoma [29, 30]. The endoplasmic reticulum has an important position as a signal integrator in both normal and malignant cells 


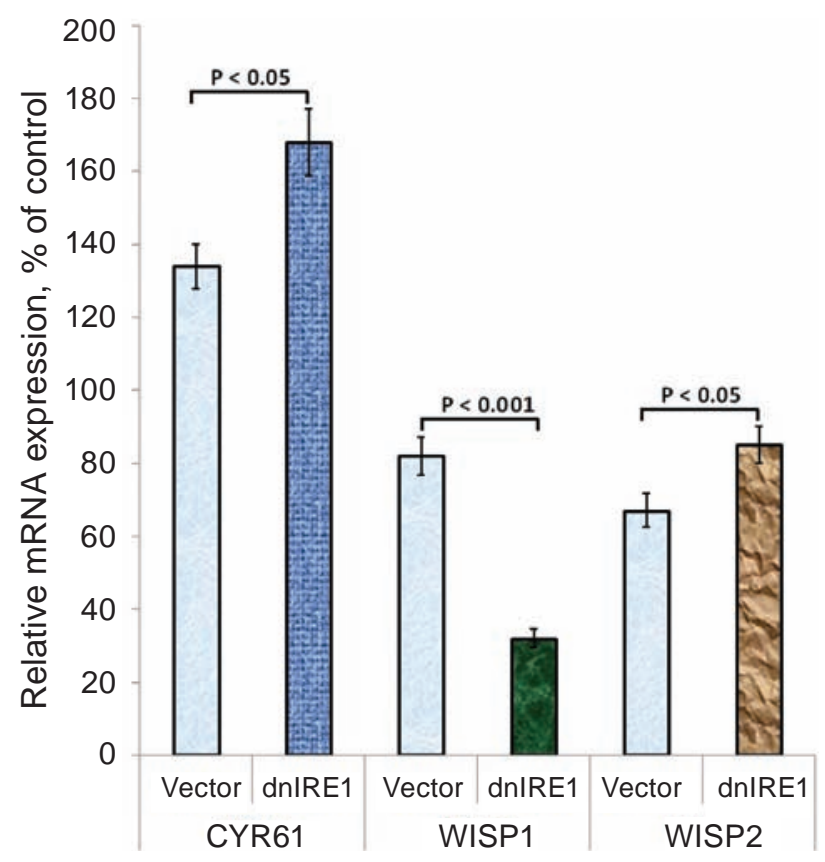

Fig. 7. Inhibition of IRE1 modifies the effect of glutamine deprivation condition on the expression of CYR61/IGFBP10, WISP1, and WISP2 mRNA in glioma cells (by qPCR). These mRNA expressions values were normalized to $\beta$-actin mRNA expression and represented as percent of corresponding control (both controls are taken as 100\%); mean \pm SEM; $n=4$

because the endoplasmic reticulum stress signaling pathways have connections with other plasma membrane receptor signaling networks and with numerous metabolic pathways $[15,24]$. It is known that the complete blockade of the activity of IRE1 signaling enzyme in glioma cells had anti-tumor effects $[19,20]$.

In this study we have also demonstrated that the expression of NOV, WISP1, and WISP2 genes is down-regulated in control glioma cells upon glutamine deprivation condition, but expression of CYR61 gene is up-regulated at this experimental condition. At the same time, the expression of IGFBP6 and IGFBP7 genes in control glioma cells is resistant to glutamine deprivation. However, inhibition of IRE1 signaling enzyme, which is a central mediator of the unfolded protein response and an important component of malignant tumor growth, modifies expression of all studied genes: introduces sensitivity of the expression of IGFBP6 and IGFBP7 genes to glutamine deprivation condition, and enhances the effect of this condition on CYR61 and WISP1 genes expression. These results have shown that the effect of glutamine deprivation on the expression of different studied genes is gene-specific as well as their dependence on inhibition of IRE1 signaling enzyme, indicating that glutamine deprivation introduces complex metabolic changes and their significance remains unclear. Moreover, multifunctional protein CYR61 can suppress carcinogenesis by inhibiting compensatory proliferation [34], and increased expression of its gene in control and IRE1 knockdown glioma cells upon glutamine deprivation condition can also contribute to suppression of cell proliferation after inhibition of IRE1 and invasive phenotype of these cells [20], although the role of CYR61 in tumor growth is not well established yet. At the same time, glutamine deprivation leads to down-regulation of the expression of both WISP1 and WISP2 genes in control and IRE1 knockdown glioma cells, but functional significance of these changes remains unclear yet. These genes encoded transcriptional repressors of genes associated with the epithelial-mesenchymal transition; it is undetectable in more aggressive breast cancer cells $[12,13]$.

The insulin-like growth factor binding proteins as well as IGFBP/CCN family proteins bind and regulate the availability of both IGFs with different affinity and inhibit or stimulate the growth promoting effects of the IGFs through IGF/insulin receptors and through many other signaling pathways and regulate cell proliferation and survival as well as angiogenesis and cancer cell migration [6, 11]. As shown in Fig. 8, IGFBP/CCN family proteins have several domains with different functions and can interact with various regulatory proteins.

Thus, the changes observed in the most above studied insulin-like growth factor binding proteins gene expressions correlate well with slower cell proliferation in cells harboring dnIRE1, attesting to the fact that endoplasmic reticulum stress is a necessary component of malignant tumor growth, cell survival and metastasis. Moreover, our results demonstrate that glutamine deprivation, which contributes to suppression of tumor growth, affects most studied insulin-like growth factor binding protein and WNT1 inducible signaling pathway protein genes expression, and that inhibition of IRE1 preferentially modifies the expression of these genes and thus possibly contributes to slower glioma growth. However, the detailed molecular mechanisms of IRE1-mediated regulation of these genes, which have a pivotal role in the control of cell proliferation as well as metas- 


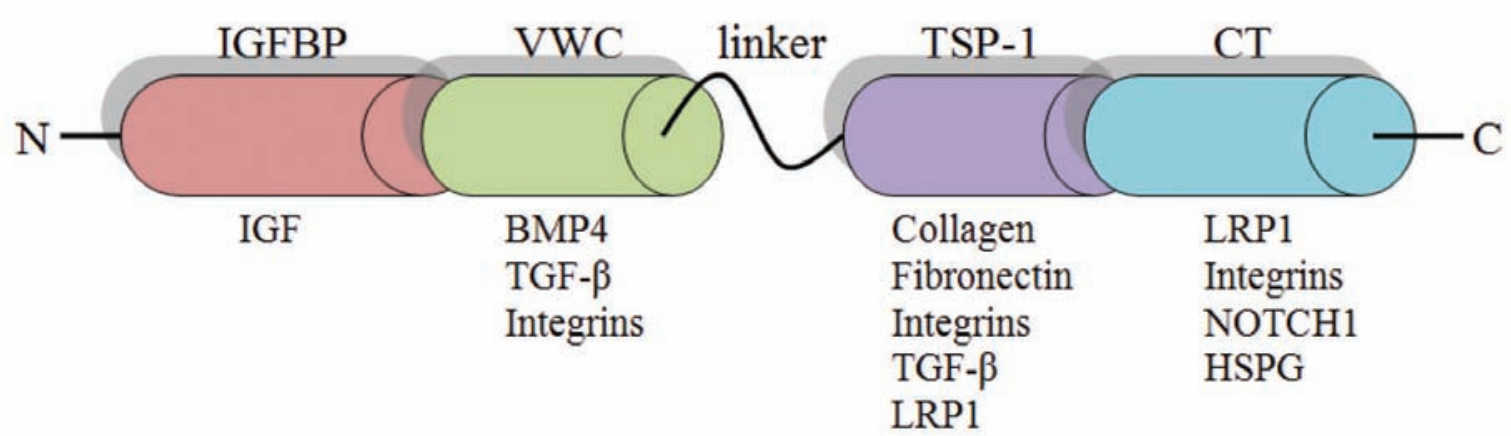

Fig. 8. Structure of CCN family proteins. Domains: IGFBP - IGF Binding Protein like, VWC - Von Willebrand Factor Type C, TSP-1 - Thrombospondin Type-1, and CT-Cysteine-Knot-Containing. Partners (at the bottom): IGF - Insulin Like Growth Factor, BMP4 - Bone Morphogenetic Protein 4, TGF- $\beta$ - Tumor Growth Factor $\beta$, LRP1 - Low Density Lipoprotein Receptor-Related Protein 1, NOTCH1 - Notch Homolog 1 Translocation-Associated, HSPG - Heparan Sulfate Proteoglycan

tasis, upon glutamine deprivation are complex and warrant further investigation.

\section{ЕКСПРЕСIЯ ГЕНIВ IGFBP6, IGFBP7, NOV, CYR61, WISP1 TA WISP2 B КЛІТИНАХ ГЛІОМИ ЛІНІЇ U87 В УМОВАХ ДЕФІЦИТУ ГЛУТАМІНУ}

О. Г. Мінченко ${ }^{1}$, А. П. Харькова ${ }^{1}$, Д. О. Мінченко, ${ }^{1,2}$, Л. Л. Карбовський

${ }^{1}$ Інститут біохімії ім. О. В. Палладіна НАН України, Київ; e-mail: ominchenko@yahoo.com;

${ }^{2}$ Національний медичний університет ім. О. О. Богомольця, Київ, Україна

Нами вивчалася експресія різних генів протеїнів, що зв'язуються 3 подібними до інсуліну факторами росту, в клітинах гліоми лінії U87 в умовах дефіциту глутаміну залежно від пригнічення IRE1 (залежного від інозитолу ензим 1), центрального медіатора стресу ендоплазматичного ретикулума. Встановлено, що витримування клітин гліоми в умовах дефіциту глутаміну призводить до зниження рівня експресії генів NOV/IGFBP9, WISP1 та WISP2 i збільшення - гена CYR61/IGFBP10 на рівні мРНК. У той самий час, експресія генів IGFBP6 та IGFBP7 є резистентною до умов дефіциту глутаміну в контрольних клітинах гліоми. Також показано, що пригнічення IRE1 модифікує ефект дефіциту глутаміну на експресію всіх досліджених генів. Так, інгібування сигнального ензиму IRE1 посилювало ефект дефіциту глутаміну на експресію генів CYR61 та WISP1 i пригнічувало його дію на експресію гена WISP2 в клітинах гліоми. Більше того, інгібування IRE1 призводило до появи чутливості до дефіциту глутаміну експресії генів IGFBP6 та IGFBP7, але знімало цю чутливість до гена NOV. Нами також показано, що експресія всіх досліджених генів у клітинах гліоми у присутності глутаміну регулюється сигнальним ензимом IRE1, оскільки пригнічення IRE1 істотно знижує експресію генів IGFBP6 та IGFBP9/NOV і посилює експресію генів IGFBP7, CYR61/IGFBP10, WISP1 та WISP2 за порівняння 3 контрольними клітинами гліоми. Результати цієї роботи продемонстрували, що дефіцит глутаміну порушує експресію більшості досліджених генів груп IGFBP та WISP залежно від функції IRE1 i, можливо, робить внесок у зниження проліферації клітин гліоми в умовах пригнічення IRE1.

Кл юч ов і слова: експресія мРНК, IGFBP6, IGFBP7, NOV/IGFBP9, CYR61/IGFBP10, WISP1, WISP2, пригнічення IRE1, дефіцит глутаміну, клітини гліоми. 


\section{ЭКСПРЕССИЯ ГЕНОВ IGFВP6, IGFBP7, NOV, CYR61, WISP1 И WISP2 В КЛЕТКАХ ГЛИОМЫ ЛИНИИ U87 ПРИ ДЕФИЦИТЕ ГЛЮТАМИНА}

\author{
О. Г. Минченко ${ }^{1}$, А. П. Харькова 1 , \\ Д. О. Минченко ${ }^{1,2}$, Л. Л. Карбовский
}
${ }^{1}$ Институт биохимии им. А. В. Палладина НАН Украины, Киев; e-mail: ominchenko@yahoo.com;
${ }^{2}$ Национальный медицинский университет им. А. А. Богомольца, Киев, Украина

Нами изучена экспрессия генов протеинов, связывающихся с подобными инсулину факторами роста, в клетках глиомы линии U87 при дефиците глютамина в зависимости от угнетения IRE1 (зависимого от инозитола энзима 1), центрального медиатора стресса эндоплазматического ретикулума. Установлено, что выдерживание контрольных клеток глиомы при дефиците глютамина приводит к снижению уровня экспрессии генов IGFBP9/NOV, WISP1 и WISP2 и усилению - гена CYR61/IGFBP10 на уровне мРНК. В то же время экспрессия генов IGFBP6 та IGFBP7 резистентна к дефициту глютамина в контрольных клетках глиомы. Также показано, что угнетение IRE1 модифицирует эффект дефицита глютамина на экспрессию всех исследованных генов. Так, ингибирование сигнального энзима IRE1 усиливало эффект дефицита глютамина на экспрессию генов CYR61 и WISP1 и снижало его действие на экспрессию гена WISP2 в клетках глиомы. Более того, ингибирование IRE1 приводило к развитию чувствительности экспрессии генов IGFBP6 и IGFBP7 к дефициту глютамина, но снимало эту чувствительность к гену NOV. Нами также показано, что экспрессия всех исследованных генов в клетках глиомы в присутствии глютамина регулируется сигнальным энзимом IRE1, поскольку его угнетение существенно снижает экспрессию генов IGFBP6 и NOV/IGFBP9 и усиливает экспрессию генов IGFBP7, CYR61/IGFBP10, WISP1 и WISP2 по сравнению с контрольными клетками глиомы. Результаты работы продемонстрировали, что дефицит глютамина нарушает экспрессию большинства исследованных генов групп IGFBP и WISP в зависимости от функции IRE1 и, возможно, играющих определенную роль в снижении пролиферации клеток глиомы при угнетении IRE1.
Кл ючевы е слова: экспрессия мРНК, IGFBP6, IGFBP7, NOV/IGFBP9, CYR61/IGFBP10, WISP1, WISP2, угнетение IRE1, дефицит глютамина, клетки глиомы.

\section{References}

1. Pollak M. Insulin and insulin-like growth factor signalling in neoplasia. Nat Rev Cancer. 2008; 8(12): 915-928.

2. Ozcan U, Cao Q, Yilmaz E, Lee AH, Iwakoshi NN, Ozdelen E, Tuncman G, Görgün C, Glimcher LH, Hotamisligil GS. Endoplasmic reticulum stress links obesity, insulin action, and type 2 diabetes. Science. 2004; 306(5695): 457-461.

3. Kuijjer ML, Peterse EF, van den Akker BE, Briaire-de Bruijn IH, Serra M, Meza-Zepeda LA, Myklebost O, Hassan AB, Hogendoorn PC, Cleton-Jansen AM. IR/IGF1R signaling as potential target for treatment of high-grade osteosarcoma. BMC Cancer. 2013; 13: 245.

4. Lee J, Ozcan U. Unfolded protein response signaling and metabolic diseases. $J$ Biol Chem. 2014; 289(3): 1203-1211.

5. Minchenko DO, Kharkova AP, Karbovskyi LL, Minchenko $\mathrm{OH}$. Expression of insulin-like growth factor binding protein genes and its hypoxic regulation in U87 glioma cells depends on ERN1 mediated signaling pathway of endoplasmic reticulum stress. Endocr Regul. 2015; 49(2): 73-83.

6. Baxter RC. IGF binding proteins in cancer: mechanistic and clinical insights. Nat Rev Cancer. 2014; 14(5): 329-341.

7. Ellis BC, Graham LD, Molloy PL. CRNDE, a long non-coding RNA responsive to insulin/IGF signaling, regulates genes involved in central metabolism. Biochim Biophys Acta. 2014; 1843(2): 372-386.

8. Bach LA, Fu P, Yang Z. Insulin-like growth factor-binding protein-6 and cancer. Clin Sci (Lond). 2013; 124(4): 215-229.

9. Pan $Y$, Liang $H$, Liu $H$, Li $D$, Chen $X$, Li L, Zhang CY, Zen K. Platelet-secreted microRNA-223 promotes endothelial cell apoptosis induced by advanced glycation end products via targeting the insulin-like growth factor 1 receptor. J Immunol. 2014; 192(1): 437446.

10. Evdokimova V, Tognon CE, Benatar T, Yang W, Krutikov K, Pollak M, Sorensen PH, Seth A. 
IGFBP7 binds to the IGF-1 receptor and blocks its activation by insulin-like growth factors. Sci Signal. 2012; 5(255): ra92.

11. Wagener J, Yang W, Kazuschke K, Winterhager E, Gellhaus A. CCN3 regulates proliferation and migration properties in Jeg3 trophoblast cells via ERK1/2, Akt and Notch signalling. Mol Hum Reprod. 2013; 19(4): 237-249.

12. Schlegelmilch K, Keller A, Zehe V, Hondke S, Schilling T, Jakob F, Klein-Hitpass L, Schütze N. WISP 1 is an important survival factor in human mesenchymal stromal cells. Gene. 2014; 551(2): 243-254.

13. Gurbuz I, Chiquet-Ehrismann R. CCN4/WISP1 (WNT1 inducible signaling pathway protein 1): a focus on its role in cancer. Int $J$ Biochem Cell Biol. 2015; 62: 142-146.

14. Xie D, Nakachi K, Wang $H$, Elashoff $R$, Koeffler HP. Elevated levels of connective tissue growth factor, WISP-1, and CYR61 in primary breast cancers associated with more advanced features. Cancer Res. 2001; 61(24): 8917-8923.

15. Yadav RK, Chae SW, Kim HR, Chae HJ. Endoplasmic reticulum stress and cancer. J Cancer Prev. 2014; 19(2): 75-88.

16. Hetz C, Chevet E, Harding HP. Targeting the unfolded protein response in disease. Nat Rev Drug Discov. 2013; 12(9): 703-719.

17. Clarke HJ, Chambers JE, Liniker E, Marciniak SJ. Endoplasmic reticulum stress in malignancy. Cancer Cell. 2014; 25(5): 563-573.

18. Pluquet O, Dejeans N, Chevet E. Watching the clock: endoplasmic reticulum-mediated control of circadian rhythms in cancer. Ann Med. 2014; 46(4): 233-243.

19. Drogat B, Auguste P, Nguyen DT, Bouchecareilh M, Pineau R, Nalbantoglu J, Kaufman RJ, Chevet E, Bikfalvi A, Moenner M. IRE1 signaling is essential for ischemia-induced vascular endothelial growth factor-A expression and contributes to angiogenesis and tumor growth in vivo. Cancer Res. 2007; 67(14): 67006707.

20. Auf G, Jabouille A, Guérit S, Pineau R, Delugin $M$, Bouchecareilh M, Magnin N, Favereaux A, Maitre $M$, Gaiser $T$, von Deimling A, Czabanka M, Vajkoczy P, Chevet E, Bikfalvi A, Moenner M. Inositol-requiring enzyme lalpha is a key regulator of angiogenesis and invasion in malignant glioma. Proc Natl Acad Sci USA. 2010; 107(35): 15553-15558.
21. Auf G, Jabouille A, Delugin M, Guérit S, Pineau R, North S, Platonova N, Maitre M, Favereaux A, Vajkoczy P, Seno M, Bikfalvi A, Minchenko D, Minchenko O, Moenner M. High epiregulin expression in human U87 glioma cells relies on IRE1 $\alpha$ and promotes autocrine growth through EGF receptor. BMC Cancer. 2013; 13: 597.

22. Acosta-Alvear D, Zhou Y, Blais A, Tsikitis M, Lents $\mathrm{NH}$, Arias C, Lennon CJ, Kluger $\mathrm{Y}$, Dynlacht BD. XBP1 controls diverse cell typeand condition-specific transcriptional regulatory networks. Mol Cell. 2007; 27(1): 53-66.

23. Pluquet $O$, Dejeans $N$, Bouchecareilh $M$, Lhomond S, Pineau R, Higa A, Delugin M, Combe C, Loriot S, Cubel G, Dugot-Senant N, Vital A, Loiseau H, Gosline SJ, Taouji S, Hallett M, Sarkaria JN, Anderson K, Wu W, Rodriguez FJ, Rosenbaum J, Saltel F, FernandezZapico ME, Chevet E. Posttranscriptional regulation of PER1 underlies the oncogenic function of IRE $\alpha$. Cancer Res. 2013; 73(15): 4732-4743.

24. Manié SN, Lebeau J, Chevet E. Cellular mechanisms of endoplasmic reticulum stress signaling in health and disease. 3. Orchestrating the unfolded protein response in oncogenesis: an update. Am J Physiol Cell Physiol. 2014; 307(10): C901-C907.

25. Minchenko DO, Danilovskyi SV, Kryvdiuk IV, Hlushchak NA, Kovalevska OV, Karbovskyi LL, Minchenko OH. Acute L-glutamine deprivation affects the expression of TP53-related protein genes in U87 glioma cells. Fiziol Zh. 2014; 60(4): 11-21.

26. Wise DR, DeBerardinis RJ, Mancuso A, Sayed N, Zhang XY, Pfeiffer HK, Nissim I, Daikhin E, Yudkoff M, McMahon SB, Thompson CB. Myc regulates a transcriptional program that stimulates mitochondrial glutaminolysis and leads to glutamine addiction. Proc Natl Acad Sci USA. 2008; 105(48): 18782-18787.

27. Fogal V, Babic I, Chao Y, Pastorino S, Mukthavaram R, Jiang P, Cho YJ, Pingle SC, Crawford JR, Piccioni DE, Kesari S. Mitochondrial p32 is upregulated in Myc expressing brain cancers and mediates glutamine addiction. Oncotarget. 2015; 6(2): 1157-1170.

28. Colombo SL, Palacios-Callender M, Frakich N, Carcamo S, Kovacs I, Tudzarova S, Moncada S. Molecular basis for the differential use of glucose 
and glutamine in cell proliferation as revealed by synchronized HeLa cells. Proc Natl Acad Sci USA. 2011; 108(52): 21069-21074.

29. Krall AS, Christofk HR. Rethinking glutamine addiction. Nat Cell Biol. 2015; 17(12): 1515-1517.

30. Tardito S, Oudin A, Ahmed SU, Fack F, Keunen O, Zheng L, Miletic H, Sakariassen PØ, Weinstock A, Wagner A, Lindsay SL, Hock AK, Barnett SC, Ruppin E, Mørkve SH, LundJohansen M, Chalmers AJ, Bjerkvig R, Niclou SP, Gottlieb E. Glutamine synthetase activity fuels nucleotide biosynthesis and supports growth of glutamine-restricted glioblastoma. Nat Cell Biol. 2015; 17(12): 1556-1568.

31. Huber AL, Lebeau J, Guillaumot P, Pétrilli V, Malek M, Chilloux J, Fauvet F, Payen L, Kfoury A, Renno T, Chevet E, Manié SN. p58(IPK)-mediated attenuation of the proapoptotic PERK-CHOP pathway allows malignant progression upon low glucose. $\mathrm{Mol}$ Cell. 2013; 49(6): 1049-1059.

32. Frewer KA, Sanders AJ, Owen S, Frewer NC, Hargest R, Jiang WG. A role for WISP2 in colorectal cancer cell invasion and motility. Cancer Genomics Proteomics. 2013; 10(4): 187196.

33. Weroha SJ, Haluska P. The insulin-like growth factor system in cancer. Endocrinol Metab Clin North Am. 2012; 41(2): 335-350.

34. Minchenko OH, Kharkova AP, Minchenko DO, Karbovskyi LL. Effect of hypoxia on the expression of genes that encode some IGFBP and CCN proteins in U87 glioma cells depends on IRE1 signaling. Ukr Biochem J. 2015; 87(6): 52-63.

35. Minchenko OH, Tsymbal DO, Moenner M, Minchenko DO, Kovalevska OV, Lypova NM. Inhibition of kinase and endoribonuclease activity of ERN1/IRE1 $\alpha$ affects expression of proliferationrelated genes in U87 glioma cells. Endoplasm Reticul Stress Dis. 2015; 2(1): 18-29.

36. Bochkov VN, Philippova M, Oskolkova O, Kadl A, Furnkranz A, KarabegE, Afonyushkin T, Gruber F, Breuss J, Minchenko A, Mechtcheriakova D, Hohensinner P, Rychli K, Wojta J, Resink T, Erne P, Binder BR, Leitinger N. Oxidized phospholipids stimulate angiogenesis via autocrine mechanisms, implicating a novel role for lipid oxidation in the evolution of atherosclerotic lesions. Circ Res. 2006; 99(8): 900-908.

37. Cheng G, Zhang H, Zhang L, Zhang J. Cyr61 promotes growth of glioblastoma in vitro and in vivo. Tumour Biol. 2015; 36(4): 2869-2873.

38. Hou CH, Lin FL, Hou SM1, Liu JF. Cyr61 promotes epithelial-mesenchymal transition and tumor metastasis of osteosarcoma by Raf-1/ MEK/ERK/Elk-1/TWIST-1 signaling pathway. Mol Cancer. 2014; 13: 236.

Received 23.05.2016 